\title{
Peran Media Sosial Sebagai Media Pemasaran dan Branding Bisnis UMKM di Era Pandemi Covid-19 di Dusun Ngloram RT01 RW 02, Desa Pilangpayung, Kecamatan Toroh, Kabupaten Grobogan
}

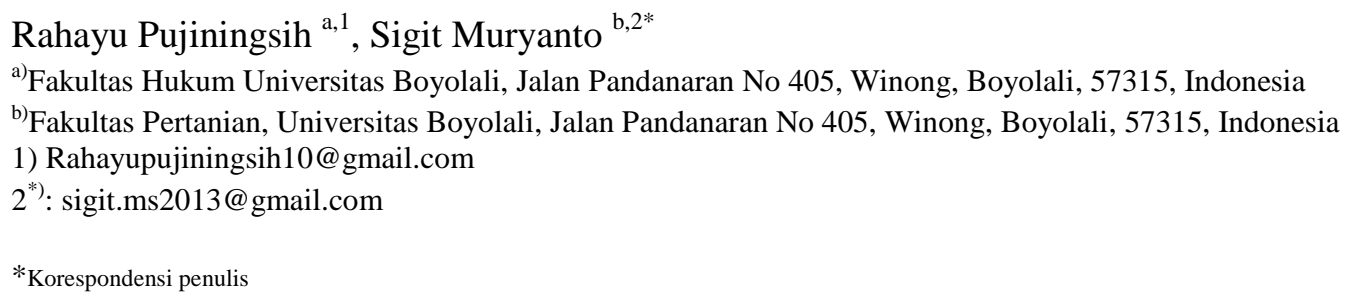

The corona virus pandemic has changed the pattern of people's lives in various fields, including the economy and business, social, politics, education and technology. In the midst of the current pandemic, small, medium and large business actors must think hard in running their business. The use of technology coupled with marketing and business branding of MSME products through social media is the solution. Social media also has many advantages for marketers, one of which is that the marketer or pelapak does not need to spend money on the cost of promoting their products, so that business people can promote as much as they want so that their products can dominate the market.

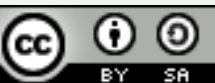

\section{Pendahuluan}

Media sosial merupakan salah satu sarana promosi penjualan dalam melakukan penjualan yang mudah dan efektif, Media sosial juga memiliki banyak keuntungan bagi pelaku usaha, salah satunya adalah pelaku usaha tidak perlu mengeluarkan biaya promosi produk mereka, dengan 
begitu pelaku usaha melalui media sosial bisa melakukan promosi penjualan sepuasnya agar produk mereka bisa terjual lebih banyak melalui online. Dalam laporan berjudul Digital 2021: The Latest Insights Into The State of Digital, disebutkan bahwa total 274,9 juta penduduk di Indonesia, 170 juta di antaranya telah menggunakan media sosial. Dengan demikian, angka penetrasinya sekitar 61,8 persen. Angka pengguna aktif media sosial di Indonesia tersebut tumbuh sebesar 10 juta atau sekitar 6,3 persen di bulan Januari 2020. [1] Dalam periode yang sama, pengguna internet di Indonesia tumbuh 27 juta atau 15,5 persen menjadi 202,6 juta.[2] Januari 2021, Indonesia memiliki pengguna internet sebanyak 202,6 juta jiwa. Jumlah tersebut meningkat sebanyak 27 juta atau 16 persen dibandingkan tahun sebelumnya. Sementara penetrasi internet mencapai $73,7 \%$ hingga Januari lalu.

Menurut saya Media sosial instagram juga mengalami pembaharuan yang sangat bagus sekali, pembaharuan salah satunya adalah instagram dapat kita setting sendiri sesuai yang kita inginkan untuk melakukan promosi atau penjualan produk di instagram tersebut. Dengan begitu sesudah pengaturan maka instagram dengan sendirinya akan memasarkan produk penjual yang sudah melakukan pengaturan instagram tadi. Dengan ini saya memilih instagram sebagai pemasaran bisnis UMKM di era pandemi Covid-19 ini karena instagram sekarang banyak digunakan oleh masyarakat untuk berkomukasi keseluruh dunia dan selain itu juga instagram langsung dapat menghubungkan link aplikasi lain untuk memasarkan serta menjual UMKM kita. Maka dari itu untuk melakukan promosi penjualan instagram merupakan salah satu sarana yang baik untuk promosi produk UMKM, karena selain penjual melakukan promosi sendiri di instagram penjual juga bisa melakukan promosi yang secara otomatis dilakukan oleh user intagram dengan catatan pelapak sudah melakukan pengaturan akun instagram mereka ke akun penjualan contoh (pakaian branded dan lain lain

\section{Metode}

Pelaksanaan program kerja KKN UBY (Universitas Boyolali) 2021 dengan memberikan edukasi bagaimana cara pelaku UMKM mempromosikan produk mereka dimasa pandemi ini. Memberian edukasi media sosial sebagai media pemasaran dan branding bisnis UMKM di era pandemi covid-19 metode secara langsung atau door to door. Pemberian edukasi secara langsung oleh pelaku UMKM atau door to door ke rumah warga yang berada di Dusun Ngloram Rt.01/Rw.02 Desa Pilangpayung, Kecamatan Toroh Kabupaten Grobogan,dengan bimbingan Dosen Pembimbing KKN Bapak Ir. Sigit Muryanto,MP. KKN dilaksanakan mulai 21 Februari 2021 sampai dengan tanggal 31 Maret 2021. Dalam Memberikan edukasi juga menggunakan metode ceramah. Menurut saya (rahayu pujiningsih) metode ceramah adalah metode yang paling memungkinkan untuk menciptakan lingkungan yang tidak mengancam dan bebas dari covid-19. 
Untuk itu warga Dusun Ngloram Rt.01/Rw.02 Desa Pilangpayung, Kecamatan Toroh Kabupaten Grobogan saat diberikan arahan bagaimana cara menjual/mempromosikan hasil UMKM mereka kita sama-sama bisa terhindar dari kerumunan dan terhindar bahaya covid-19 tersebut.

\section{Hasil dan Pembahasan}

Para pelaku UMKM harus pintar untuk melakukan penjualan, untuk tetap dapat berjualan di tengah pandemi ini. Melalui pemasaran secara digital melalui website yang dijadikan e-commerce, social media, dan membentuk tim reseller untuk menjual produknya. Promosi melalui media sosial seperti instagram yang banyak testimoni maupun komentar menimbulkan kepercayaan bagi konsumennya karena bermanfaat bagi pengguna untuk mengetahui informasi lebih. [3] Gambargambar dengan fitur HD tampil lebih cerah dan lebih bagus di timeline sehingga menimbulkan kepercayaan dan minat yang tinggi bahwa pemilik akun tersebut yang membuatnya bonafid dan produknya bermutu. Melalui media sosial Instagram dalam penjualan produk UMKM ini mengubah cara seseorang berkomunikasi yang semula satu dan dua arah, kini menjadi segala arah. Dengan begitu Ini dapat menjadi saluran penting bagi retailer yang berhubungan dengan opini konsumen yang masih belum jelas.

Promosi melalui Instagram efektif dalam menstimulasi perhatian, tetapi Instagram masih belum efektif pada tahap ketertarikan, keinginan dan tindakan. Menjual produksi UMKM melalui Instagram juga memiliki kelemahan yaitu harus rajin update instagram juga memiliki timeline yang berjalan dengan cepat sehingga sebagai pemilik bisnis harus rajin untuk memposting foto ataupun video agar produknya tetap dapat dilihat oleh para pembeli.[2] Transaksi yang kurang praktis proses transaksinya terlihat kurang praktis ketika ada konsumen ingin membeli suatu produk karena harus bertansaksi melalui aplikasi lain terlebih dahulu. Selain itu kelemahannya yaitu Spamming, banyak terlihat pada bagian komentar, semua orang bisa berkomentar pada postingan.

Media Instagram sangat cocok untuk menarik perhatian pengguna Instagramer sehingga pengguna Instagram mengetahui berbagai informasi khususnya mengenai promosi dari sebuah produk tetapi untuk tindakan pembelian masih kecil kemungkinan untuk seseorang melakukan pembelian pada produk yang di promosikan khususnya produk hasil jaitan seperti baju,mukena, dan celana panjang. Faktor untuk melakukan tindakan pembelian karena pembelian tidak hanya dari Instagram saja tetapi bisa jadi tempat pembelian lainnya misal market place yang lebih aman. Melihat jumlah pengguna yang semakin banyak, Instagram bisa menjadi lahan menaikkan profit serta melebarkan penjualan bisnis. Pada dasarnya media sosial telah mengubah bagaimana konsumen berinteraksi dan bagaimana perusahaan memasarkan atau mempromosikan produk yang akan dijual. Seiring berjalannya waktu dan pembatasan berinteraksi dengan sesama penjual dan 
pembeli pemasaran melalui media sosial sangat efektif karena pemasaran media digital mencakup penggunaan internet dan produk teknologi lain yang lebih modern. Dan pemasaran konvensional masih menggunakan media-media lama seperti surat-menyurat, iklan di radio dan televisi, atau melalui surat kabar sehingga Pemasaran konvensional terbatas dalam hal audiens / konsumen yang ditargetkan karena terbatas pada pelanggan / konsumen lokal,

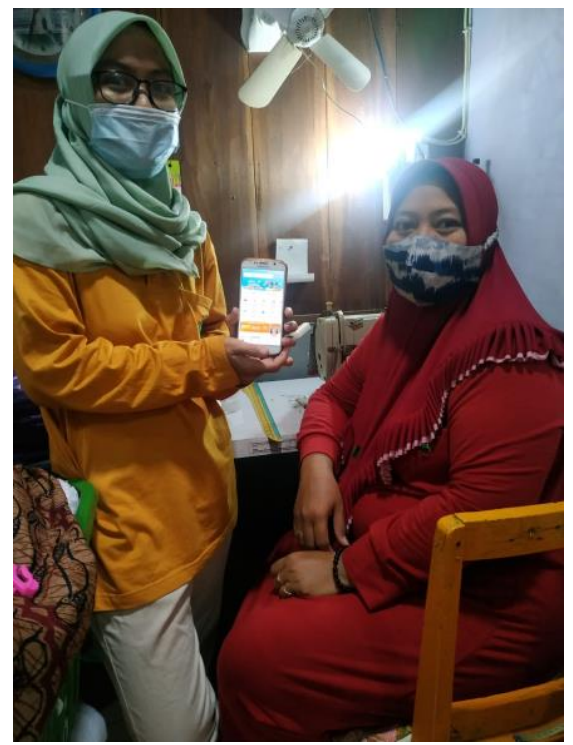

Fig. 1. Aplikasi untuk Menjual UMKM

\section{Kesimpulan}

Bahwa dengan instagram penjualan relatif meningkat daripada sebelumnya yang hanya menggunakan metode penjualan konvensional, Beberapa keuntungan yang didapat dengan menggunakan instagram sebagai media pemasaran adalah sebagai berikut:dapat diakses setiap saat. instagram dapat diakses melalui jaringan internet setiap saat, baik dari komputer maupun dari handphone, Komunikasi jadi lebih mudah. instagram menyediakan fungsi komunikasi, diantaranya fungsi pesan (message), obrolan (chat) dan lain-lain. Low Budget, High Impact. Menggunakan instagram $100 \%$ gratis, sehingga banyak penghematan yang bisa dilakukan.

\section{Saran}

1. Dalam upaya meningkatkan pendapatan dimasa pandemi Covid-19 ini pelaku UMKM lebih mendalami lagi strategi pemasarannya di Instagram,agar konsumen dan pelanggan lebih banyak lagi sehingga dalam usaha meningkatkan pendapatan dapat berjalan lebih efektif dan pelanggan tetap mempercainya.

2. Sebaiknya pelaku UMKM membuat laporan keuangan sebagai dasar dalam hal mengambil keputusan untuk melaksanan penjualan secara online di Instagram dan dalam laporan tersebut juga dapat mengontrol usaha mereka. 


\section{Ucapan Terimakasih}

Kami panjatkan syukur Alhamdulillah kepada Allah SWT yang telah memberikan 0rahmat dan hidayah Nya sehingga segala sesuatunya selalu diberikan kelancaran. Tidak lupa pula kami ucapkan terimakasih kepada Civitas Universitas Boyolali, Dosen Pembimbing Lapangan, Dusun Ngloram Rt.01/Rw.02 Desa Pilangpayung Kecamatan Toroh Kabupaten Grobogan, Orang Tua yang selalu membantu dalam pelaksaan program KKN ini, serta semua pihak yang tidak dapat kami sebutkan satu per satu yang telah memberikan bantuan dalam bentuk apapun sehingga kegiatan KKN ini dapat terlaksana dan selesai dengan baik.

\section{Daftar Pustaka}

[1] A. Ansyori and S. Shaleh, "Strategi Pemanfaatan Media Sosial Sebagai Media Pendidikan Islam Informal Pada Remaja: Solusi di Masa Pandemi Covid-19," EDUKASI J. Penelit. Pendidik. Agama dan Keagamaan, vol. 18, no. 3, p. 302, 2020, doi: 10.32729/edukasi.v18i3.887.

[2] K. Hadiwinata, H. Mundzir, and S. Muslim, "Analisis Peran Media Sosial Instagram Sebagai Media Pemasaran dan Branding Bisnis di Era Pandemi Covid-19," Senabisma, vol. 6, no. 2, pp. 62-68, 2020.

[3] P. Kurniawan, M. Syarif, and E. Amaniyah, "Instagram Sebagai Media Komunikasi Pemasaran Modern Pada Batik Tulis Khas Tanjung Bumi Bangkalan," Eco-Entrepreneur, vol. 5, no. 2, pp. 120-138, 2019. 